\title{
Effect Of Balancing Funds And Special Autonomy Funds On Economic Growth In West Papua Province (Capital Expenditure As An Intervening Variable)
}

\author{
By \\ Marthen Anton Pentury \\ Sekolah Tinggi Ilmu Administrasi Asy-Syafi'lyah Fakfak \\ Corresponding Author: pentury88@gmail.com
}

Submission: June 23, 2020; Accepted: August 19, 2020

\begin{abstract}
Economic growth in West Papua Province is intensively carried out in order to pursue better economic development compared to other regions. The impetus for regional development comes from the central government transfer namely the balance fund and the special autonomy fund. The purpose of this study was to analyze the magnitude of direct and indirect effects through intervening variable. The variables in this study are balance funds and special autonomy funds as independent variabels, capital expenditure as intervening variable and economic growth.as the dependent variable. The data source comes from BPS 2010-2019 and are analyzed using the path analysis regression method. The results showed that the balancing fund and special autonomy fund did not significantly influence capital expenditure, while the balancing fund, special autonomy fund and capital expenditure had a significant effect on economic growth. The indirect effect of balancing funds and special autonomy funds through intervening variable capital expenditure is not significant on economic growth. The regional government of West Papua Province needs more attention to the effectiveness of the regional expenditure posture in terms of the quality of the allocation of balancing funds and special autonomy funds.
\end{abstract}

Keywords: Balancing Funds, Special Autonomy Funds, Capital Expenditure, Economic Growth

\section{ABSTRAK}

Pertumbuhan ekonomi di Provinsi Papua Barat gencar dilaksanakan guna mengejar perkembangan perekonomian yang lebih baik dibandingkan daerah lain. Dorongan pembangunan daerah yang berasal dari tansfer pemerintah pusat yakni dana perimbangan dan dana otonomi khusus. Tujuan penelitian ini adalah untuk menganalisis besar pengaruh langsung dan pengaruh tidak langsung melalui variabel intervening. Variabel dalam penelitian ini yakni dana perimbangan, dana otonomi khusus, belanja modal sebagai variabel intervening dan pertumbuhan ekonomi. Sumber data berasal dari BPS tahun 20102019 dan dianalisis dengan menggunakan metode regresi analisis jalur (path analysis). Hasil penelitian menunjukkan bahwa dana perimbangan dan dana otonomi khusus tidak berpengaruh signifikan terhadap belanja modal, sedangkan dana perimbangan, dana otonomi khusus dan belanja modal berpengaruh signifikan terhadap pertumbuhan ekonomi. Pengaruh tidak langsung dana perimbangan dan dana otonomi khusus melalui variabel intervening belanja modal tidak signifikan terhadap pertumbuhan ekonomi. Pemerintah daerah Provinsi Papua Barat perlu memperhatikan efektivitas postur belanja daerah dalam hal kualitas alokasi dana perimbangan dan dana otonomi khusus.

Kata Kunci: Dana perimbangan, Dana Otonomi Khusus, Belanja Modal, Pertumbuhan Ekonomi 


\section{INTRODUCTION}

Sustainable development focuses to promote economic growth (Presidential Regulation Number 72 of 2018). Indonesia as an archipelago with the main objective of development equality of social justice must carry out development in each region including the most remote areas in order to create a structured, integrated, sustainable and continuous system. The synergy between the central government and regional government in the process of regional development is very important, because the regional government understands better the conditions in the region. Regional development aims to make local governments and their communities manage resources by developing partnerships with the private sector in creating jobs and stimulating regional economic growth (Kuncoro, $2004: 110$ ).

In an effort to realize the regional development goals, the regional government must be given the authority to act as the coordinator as well as the main facilitator in accordance with its function and role in determining new policy and or strategy for regional development. This is important and urgent to be implemented, because inequality in economic development among regions may have a wide impact, growth will be concentrated in one area and other regions will be left behind. Decentralization policy through regional autonomy in the administration of government is one of the democratic policies in accommodating the interests and demands of the community in terms of governance and development in the regions. The desire and expectation of decentralization of governance in the regions has been accommodated by the central government with the issuance of Act Number 23 of 2014 along with amendments on Act Number 9 of 2015 on the spirit of regional autonomy.

In the structure of the regional government budget / anggaran pendapatan dan belanja daerah (APBD), one of the regional revenues originating from central government transfers to autonomous regions is the Balancing Fund, which consists of tax revenue sharing, non-tax revenue sharing, general allocation funds/dana alokasi umum (DAU), and special allocation funds/dana alokasi khusus (DAK). The balancing fund is expected to be able to finance regional development process with economic growth as the main indicator of its success.

The financing of the development process in the context of regional financial management, referred to as regional expenditure and in the Governmental Regulation Number 12 of 2019 on the Regional Financial Management (article 1 section 13 and 14) is all regional government obligations recognized as a deduction of net worth in the period of the budget year. While financing is any revenue that needs to be paid back and/or expenses to be received again, both in the budget year concerned and in the following fiscal/budget years.

The regional expenditure budget in the APBD structure consists of indirect and direct expenditure. The indirect expenditure group is budgeted expenditure that is not directly related to the implementation of programs and activities while direct expenditure is budgeted expenditure directly related to the implementation of programs and activities (Anggarini \& Puranto, $2010: 135$ ). The purpose of the implementation of programs and activities here is directly related to regional development programs and activities carried out to increase the availability of facilities and infrastructure to support the economy of a region.

Economic development is reflected in an increase or decrease in economic activity. Sectors forming the gross regional domestic product influence in stimulating and moving the economy so that the alignment of central and regional policies can optimize regional economic growth. The development of West Papua Province's economic growth, which is seen in the gross regional domestic product and the balance funds, special autonomy funds and capital expenditure can be seen in the following figure. 


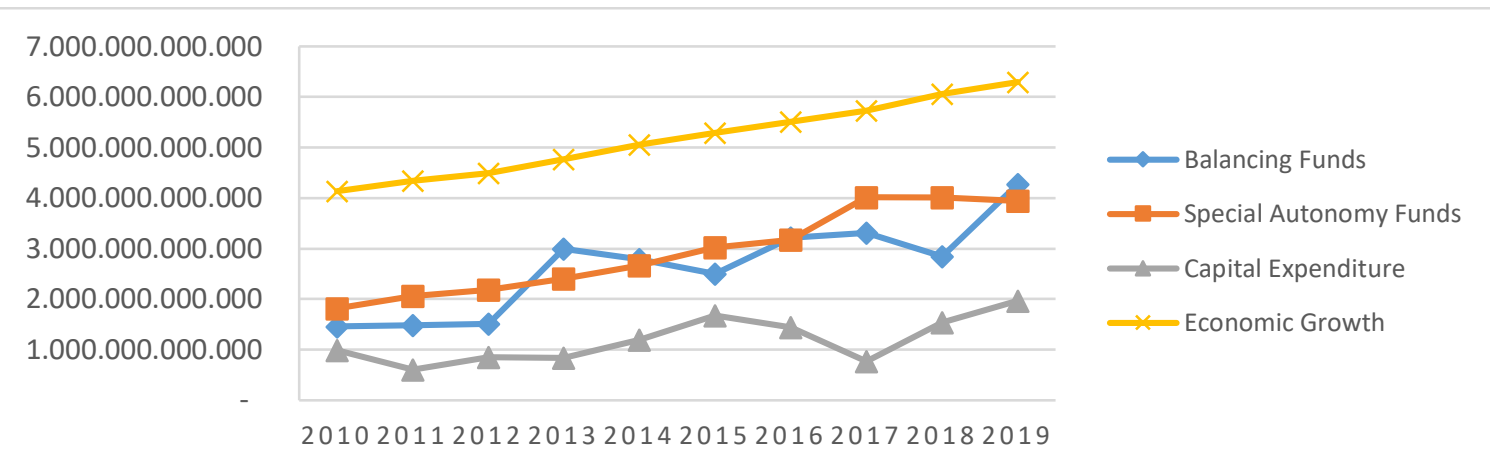

Figure 1. Balancing Funds, Special Autonomy Funds, Capital Expenditures and Economic Growth in West Papua Province, 2010-2019

Source: BPS, West Papua Province, 2020

The figure 1 above shows that the economic growth of West Papua Province grew positively, meaning that there was an increase in growth from year to year with an average growth of 4.78 percent. A positive increase indicates that the economy has been in the right direction regardless of the size of the increase in growth. However, if we look at the macro economy, as a region with additional special autonomy funds, then it is appropriate if the availability of funds is able to encourage regional economic growth on a larger scale, sustainably and continuously.

The development of balancing funds tends to fluctuate with an average growth of 16 percent where the growth reaching 50 percent in 2019. The special autonomy fund has the same fluctuation trend with an average of 9.2 percent and the highest growth of 26.5 percent in 2015. The objective of decentralized policies is the division of duties between the central government and the government region. The impact of decentralization policy is financing that can meet the needs of the implementation of duties and authority. With balancing funds coupled with special autonomy funds, then the support for financing the economic development should have a real impact on regional economic growth.

Suparmoko (2012: 1), states that State finance is a study of the effects of the State Budget / Anggaran Pendapatan dan Belanja Negara (APBN) on the economy, especially its effects on achieving the objectives of economic activity, price stability, equitable distribution of income and an increase in efficiency as well as creation of job opportunities. The Act Number 23 of 2014 about Regional Government stipulates that regional government are implemented based on the principles of decentralization, the principle of deconcentration and the principle of co-administration, with the presence of the delegation of authority, then the provincial government and city government are formed and compiled as autonomous regions. Furthermore, decentralization is the handing over of government affairs by the Central Government to autonomous regions based on the principle of autonomy to regulate and manage government affairs in increasing regional own-source revenue and the implementation of regional autonomy in order to achieve one of the objectives of the state, especially in order to provide better public services and create a more democratic public decision making process. Fiscal decentralization is a process of budget distribution from higher levels of government to lower governments to carry out the functions or tasks of government effectively and get freedom of decision making in the provision of public services in accordance with the many authorities in the field of government delegated (Saragih, 2003: 83).

The Balancing Fund is a source of regional income that comes from the APBN to support the implementation of regional government authority in achieving the goal of autonomy granting to the regions, which is primarily an increase in services and better community welfare (Widjaja, $2002 ; 47$ ). According to Act No. 33 of 2004 on Fiscal Balance between the Central and Regional Governments (Article 1 section 19), it is stated that the Balancing Fund is a fund sourced from the APBN revenue allocated to the Regions to fund the regional needs in the context of the implementation of Decentralization. 
In general, according to Elmi (2002: 56), the general purpose of the central government to transfer funds to local governments is, first, as a concrete action to reduce the imbalance in the distribution of "national cake", both vertical and horizontal. Second is an effort to improve the efficiency of government expenditure by giving up some authority in the field of state financial management and so that the benefits generated can be enjoyed by the people in the region concerned. Fiscal imbalance that had occurred between the central and regional governments had caused regional financial dependence on assistance from the central government.

Davoodi and Zou (1998: 249) said that fiscal decentralization will lead to competition among the regions which will ultimately increase the equality between what is expected by the people and the programs carried out by their local governments. Oates (1993: 239) states that the level of economic progress is an outcome of the conformity of community preferences with the local government which created due to the increasingly important role of local government in regional autonomy. Theoretically, fiscal decentralization is expected to provide economic improvement given that local governments are close to their communities and have an information advantage over the central government, so that local governments can provide the priority public services needed in their regions in a relatively short time.

Special autonomy is enforced in West Papua Province through Act No. 35 of 2008 concerning the enactment of Government Regulation Number 1 of 2008 on the Amendments to Act Number 21 of 2001 about Special Autonomy for the Province of Papua became the law. In addition, additional infrastructure funds were also allocated.

According to Sukirno $(2011 ; 331)$, economic growth is defined as the development of activities in the economy which increases the goods and services produced in the community and the prosperity. So that economic growth measures the achievement of the development of an economy from one period to another. The ability of a country to produce goods and services will increase. This increase in capability is due to the increase in production factors both in quantity and quality. Investment will add capital goods and the technology used is also growing.

Research on the effect of balancing funds on economic growth has been conducted by Chandra, et.al (2017: 67); Wiraswastha, et.al (2018) ; Paat., et.al (2015) using OLS regression models and path analysis. Fajri (2016); Putra and Dewi (2018) about the effect of balancing funds on capital expenditure using OLS regression analysis and path analysis. The difference between this study compared to previous studies lies in the use of intervening variables and the structural relationship mechanism between the dependent variable and the independent variable.

The purpose of this study was to determine the magnitude of the direct influence of the balance fund and special autonomy fund on capital expenditure, as well as the effect of the balance fund, special autonomy fund and capital expenditure on economic growth in the province of West Papua. Furthermore, It also aims to find out the magnitude of the indirect effect of balancing funds and special autonomy funds through intervening variable of capital expenditure on economic growth in the province of West Papua. Theoretically the benefits of this research are as a reference for research that has the scope of the study of regional growth, and practical benefits for local governments can be used as an academic reference in formulating appropriate policy directions for further regional economic growth.

\section{METHODS}

Muhidin and Abdurahman (2011: 221), said that in the study of statistics for the purpose of forecasting/ estimating the value of $\mathrm{Y}$ on the basis of the value of $\mathrm{X}_{1}, \mathrm{X}_{2}, \ldots . ., \mathrm{X}_{\mathrm{i}}$, the corresponding relationship pattern is the pattern of relationships that follows the regression model, while to analyze the pattern of causal relationships between variables with the aim to determine the direct and indirect effects, both simultaneously or independently of some of the causal variables on an effect variable, then the right pattern is the path analysis model. Path analysis model is used to answer the research problem. The type of data in this study is time series, period of 2010-2019, sourced from the Central Statistics Agency/Badan Pusat Statistik (BPS) of West Papua Province and the Directorate General of Fiscal Balance, Ministry of Finance of the Republic of Indonesia. 
Kadir (2013: 2) states that the indirect effect of several independent variables on a dependent variable is through another variable called the intervening variable. For this purpose, to simplify the process and structure of the analysis, a path diagram is needed. Harun Al-Rasyid [(2005, in Muhidin and Abdurahman (2011): 222], said that path diagram is a diagram that requires a structured relationship among the variables.

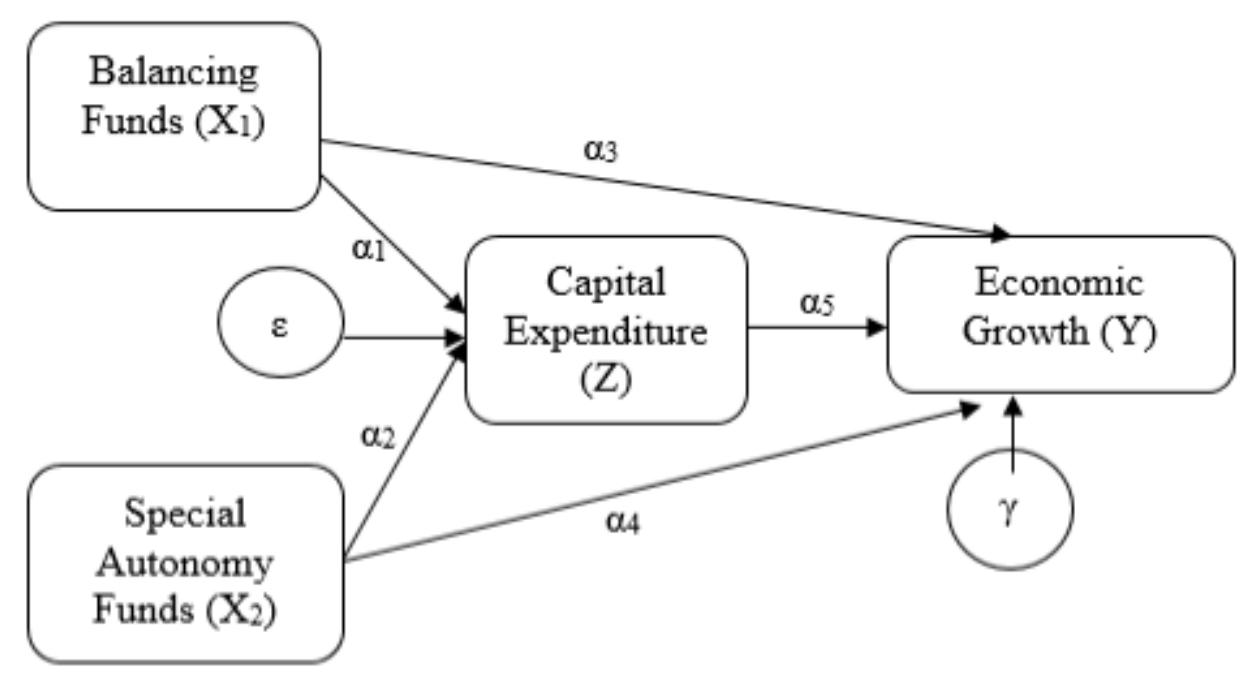

Figure 2. Model of Path Analysis of the Effect of Balancing Funds and Special Autonomy Funds on

Economic Growth in West Papua Province (Capital Expenditures as Intervening Variable)

Path analysis is an extension of multiple linear regression analysis. Path analysis uses regression analysis to estimate causality relationships among the variables (causal models) that have been predetermined based on theory (Khuzaini, 2009: 169). Based on Figure 2, mathematically path analysis can be formed into a set of regression equation models, as follows:

$$
\begin{aligned}
& Z=\alpha_{1} X_{1}+\alpha_{2} X_{2}+\varepsilon \ldots \ldots \ldots . . . \\
& Y=\alpha_{3} X_{1}+\alpha_{4} X_{2}+\alpha_{5} Z+\gamma .
\end{aligned}
$$

Where, the variables used in this study consisted of $X_{1}$ is the balance fund; $X_{2}$ is a special autonomy fund; $Z$ is capital expenditure, and; $Y$ is economic growth. Whereas $\alpha_{1}, \alpha_{2}, \alpha_{3}, \alpha_{4}, \alpha_{5}$ is the regression coefficient of each variable, as well as $\varepsilon$ and $\gamma$ is error term.

\section{RESULTS AND DISCUSSION}

\section{Direct Effect}

The research results showed a causal relationship among variables arranged in a temporary order using the path coefficient as a value in determining the magnitude of the influence of exogenous independent variables on endogenous dependent variables (Sarwono, 2012: 129). A summary of the path analysis model estimation results can be seen in the following table.

Table 1. Path Analysis Estimation Results

\begin{tabular}{lccccc}
\hline \multirow{2}{*}{$\begin{array}{c}\text { Variable } \\
\text { Relationship }\end{array}$} & \multicolumn{2}{c}{ Unstandardized Coefficients } & $\begin{array}{c}\text { Standardized } \\
\text { Coefficients }\end{array}$ & t & Sig. \\
\cline { 2 - 4 } & $\mathrm{B}$ & SE & $\mathrm{B}$ & & \\
\hline $\mathrm{X}_{1} \rightarrow \mathrm{Z}$ & 0.202 & 0.247 & 0.414 & 0.818 & 0.440 \\
$\mathrm{X}_{1} \rightarrow \mathrm{Y}$ & 0.129 & 0.051 & 0.162 & 2.522 & 0.045 \\
$\mathrm{X}_{2} \rightarrow \mathrm{Z}$ & 0.131 & 0.272 & 0.245 & 0.483 & 0.644 \\
$\mathrm{X}_{2} \rightarrow \mathrm{Y}$ & 0.638 & 0.055 & 0.726 & 11.657 & 0.000 \\
$\mathrm{Z} \rightarrow \mathrm{Y}$ & 0.326 & 0.075 & 0.199 & 4.354 & 0.005 \\
\hline
\end{tabular}

Source: data processed 
The table above shows the relationship of variables in the path coefficient. The structural model from the estimation results can be written as follows:

Structural equation $1: Z=0.414 \mathrm{X}_{1}+0.245 \mathrm{X}_{2}+\varepsilon$

Structural equation $2: Y=0.162 X_{1}+0.726 X_{2}+0.199 Z+\gamma$

The results of the structural equation analysis 1 , explain that the balancing fund $\left(X_{1}\right)$ and special autonomy fund $\left(X_{2}\right)$ have no significant effect on capital expenditure $(Z)$. While the structural equation 2 shows that the balancing fund $\left(X_{1}\right)$, special autonomy fund $\left(X_{2}\right)$ and capital expenditure $(Z)$ have a significant effect on economic growth $(\mathrm{Y})$. follows.

The results of the path coefficient summary obtained can be illustrated in the path diagram as

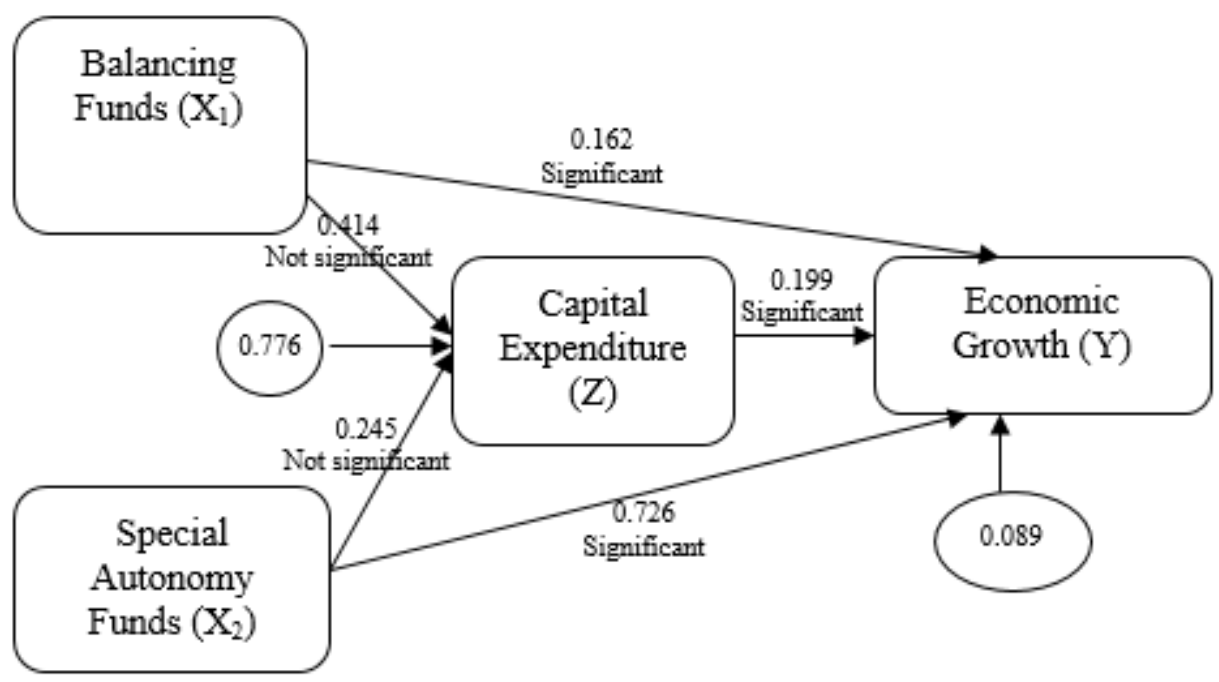

Figure 2. Path Analysis Model Diagram Source: data processed

The values of $\varepsilon$ (structural equation 1 ) and $\gamma$ (structural equation 2 ) are calculated using the formula, so that obtained the value of $\varepsilon=0.776$ and the value of $\gamma=0.089$. The coefficient of total determination conducted to check the validity of the model in this study, where the results of the total determination coefficient obtained with the formula: $R_{m}^{2}=1-(p \varepsilon)^{2}(p \gamma)^{2}=1-(0.776)^{2}(0.089)^{2}=0.996$. Where $\mathrm{R}_{\mathrm{m}}{ }_{\mathrm{m}}$ is total determination coefficient, $\varepsilon$ and $\gamma$ is the standard error term value. The value of the total determination coefficient is 0.996 which means that 99 percent of economic growth is influenced by balancing funds, special autonomy funds and regional expenditure while the rest is explained by other factors outside the model.

\section{The Effect of Balancing Funds and Special Autonomy Funds on Capital Expenditures}

The estimation results of the model in this study indicate that the balance funds do not have significant effect on capital expenditure with a $p$-value of $0.440>0.05$. While the special autonomy fund also does not significantly influence the capital expenditure with a p-value of $0.644>0.05$. Capital expenditure is budget expenditure for the acquisition of fixed assets and other assets that provide benefits over one fiscal year. Capital expenditure includes, among others, capital expenditure for the acquisition of land, construction and building, equipment and intangible assets (Erlina, 2015: 155). The results obtained in this study that the balance fund is not significant in influencing capital expenditure.

At the same time, research from Kusumadewi and Rahman (2007: 78), examines the flypaper effect on general allocation funds and local own-source revenue on regional expenditure in regencies/cities in Indonesia, shows that decentralization has not yet run well in Indonesia due to the high flypaper effect. Cyrenne and Pandey (2015: 327), in their study in Quebec Canada, showed that the 
transfer of funds from the central government resulted in the fact that local governments tend not to spend these funds on productive financing.

\section{The Effect of Balancing Funds, Special Autonomy Funds and Capital Expenditures on Economic Growth}

The estimation results show that the balance fund has a regression coefficient of 0.162 which means that the balance fund has a positive and significant effect on economic growth with a p-value of 0.045 $<0.05$. Based on Act No. 3 of 2003 balance funds are funds sourced from the APBN which are allocated to regions to fund regional needs in the context of the implementation of decentralization. Meanwhile according to the Governmental Regulation No. 55 of 2005 on the balancing funds aims to assist regions in order to fund their authority, also aims to reduce the imbalance of government funding sources between the center and regions and reduce funding disparities among the regions, this objective that makes the positive impact of balance fund on economic growth. The results of the study of Wiraswasta et al (2018: 177), are in line with the results of this study which indicate that the balance fund has a positive and significant effect on economic growth.

The special autonomy fund has a regression coefficient of 0.726 meaning that the special autonomy fund has a positive and significant effect on economic growth with a $p$-value of $0.000<0.05$. The West Papua special autonomy fund became one of the instruments to accelerate regional development in the province of West Papua. The efficiency and effectiveness of its management in a good government framework is important to be implemented related to outputs and outcomes for the region. The results obtained are in line with Anwar et al. (2018:11) who examined the effect of regional own-source revenues, special autonomy funds and capital expenditures on regency/city gross regional domestic product in Papua Province. The results show that the special autonomy fund has significant influence on the GRDP indicating that with the existence of special autonomy funds in Papua, then regional development is faster in catching up with other regions.

Capital expenditure has a positive and significant effect on economic growth with a regression coefficient of 0.199 and a p-value of $0.005<0.05$. According to Government Regulation Number 12 of 2019 (article 55 section 3), capital expenditure is a budget expenditure for the acquisition of fixed assets and other assets that provide benefits more than 1 (one) fiscal period. Some of the main categories of capital expenditure are: land; equipment and machinery; constructions and buildings; roads, irrigation and networks and other physical capital. Stepanus (2013:75), examining the effect of capital expenditure and local own revenue on economic growth in regencies / cities in West Kalimantan Province, the results of the study showed that capital expenditure had a positive and significant effect on economic growth in West Kalimantan Province.

\section{Indirect Effect}

The indirect relationships of the balancing funds and special autonomy funds through intervening variable capital expenditure on economic growth in the province of West Papua can be seen at Table 2 .

Table 2. The Estimation Results of Indirect Effects

\begin{tabular}{ccccc}
\hline Variable Relationship & Intervening Variable & ab & Sab & Z \\
\hline$X_{1} \rightarrow Y$ & $Z$ & 0.065 & 0.080 & 0.803 \\
$X_{2} \rightarrow Y$ & $Z$ & 0.042 & 0.088 & 0.478 \\
\hline
\end{tabular}

Source: Data processed

The table above shows that for the variable of balance funds and special autonomy funds, the magnitude of z-calculate value is smaller than the z-table. Thus, it indicates that the capital expenditure variable $(Z)$ is not an intervening variable in the balancing fund $\left(X_{1}\right)$ and special autonomy fund $\left(X_{2}\right)$ on economic growth $(Y)$ in West Papua Province. So it can be said that the balance funds and special autonomy funds do not affect indirectly on economic growth through capital expenditure. 


\section{CONCLUSION}

The results of the analysis in this study indicate that the balance fund, capital expenditure and the special autonomy fund have a significant direct effect on economic growth in the province of West Papua, in line with the results of research conducted by Chandra et.al (2017); Wiraswasta, et.al (2018); Paat., Et.all, that the balance fund is positive and significant to economic growth. However, if capital expenditure is moderated, the balance fund and special autonomy fund are not significant to economic growth, because capital expenditure in the short term only to land, building, equipment, and intangible assets.

Regional independence alone is not enough, but necessary, systematic, organized and integrated cooperation among the various sectors and fields in government so that it is expected to be more responsive in building optimal cooperation among the government agencies. Budget management that is more open and accessible to the community so that there is positive feedback from various groups as an evaluation and control function on the regional development. This research is only limited to measuring the direct and indirect effect of the balance fund and special autonomy funds on economic growth through the capital expenditure of the West Papua province government without examining in detail what causes it to happen. Other than that,

\section{REFERENCES}

Anwar Dwi Rosita A., Abdullah Faisal M., Syamsul Hadi. 2018. Analisis Pengaruh Pendapatan Asli Daerah, Dana Otonomi Khusus dan Belanja Modal terhadap PDRB di Kabupaten/Kota di Provinsi Papua. Jurnal IImu Ekonomi. Vol. 2. Jilid I. P. 1-13. (diambil pada tanggal 20 Juli 2020 dari ejournal umm)

Cyrenne, P. dan M. Pandey. 2015. Fiscal Equalization, Government Expenditures and Endogenous Growth. International Tax and Public Finance 22(2): 311-329. (diambil pada tanggal 20 Juli 2020 dari ideas.repec.org)

Davoodi, H \& Zou, H. 1998. Fiskal Decentralization and Economic Growth: A Cross-Country Study, Journal of Urban Economics, 43, 244-257. (diambil pada tanggal 21 Juli 2020 dari sciencedirect)

Elmi, Bachrul, 2002. Kebijakan Desentralisasi Fiskal Kaitannya dengan Hutang Luar Negeri Pemerintah Daerah Otonom. Kajian Ekonomi dan Keuangan, Vol. 6 No. 4. (diambil pada tanggal 21 Juli 2020 dari situs fiscal kemenkeu)

Erlina, 2015. Akuntansi Keuangan Daerah Berbasisi Akrual Berdasarkan PP Nomor 17 Tahun 2010 dan Permendagri Nomor 64 Tahun 2013, Jakarta; Salemba Empat.

Kadir, 2013. Analisis Jalur (Path Analysis), Materi Workshop Percepatan Studi S2 dan S3. Jakarta. Khuzaini. 2009. Analisis Jalur Dalam Fungsi Pelayanan terhadap Loyalitas Nasabah dengan

Purna-Pelayanan sebagai Variabel Intervening; Studi Kasus Di BPR Ponorogo. Jurnal Ekuitas Vol. 13 No. 2 Juni 2009: hal. 157 - 175. (diambil pada tanggal 21 Juli 2020 dari ejournal stiesia)

Kuncoro M., 2004, Otonomi dan Pembangunan Daerah, Erlangga.

Kusumadewi Diah Ayu dan Arif Rahman. 2007. Flypaper Effect pada Dana Alokasi Umum (DAU) dan Pendapatan Asli Daerah (PAD terhadap Belanja Daerah pada Kabupaten/Kota di Indonesia. Jurnal Akuntansi dan Auditing Indonesia. Vol. 11 No. 1. Hal. 67 - 80. (diambil pada tanggal 22 Juli 2020 dari ejournal uii).

Muhidin, Sambas Ali dan Maman Abdurahman, 2011. Analisis Korelasi, Regresi, dan Jalur Dalam Penelitian, Bandung: Pustaka Setia.

Oates, W.E, 1993. Fiscal Decentralization and Economics Development, National Tax Journal 46, 237243.

Saragih, Juli Panglima. 2003. Desentralisasi Fiskal dan Keuangan Daerah dalam Otonomi. Cetakan Pertama. Penerbit Ghalia Indonesia: Jakarta.

Sarwono J. 2012. Path Analysis dengan SPSS: Teori, Aplikasi, Prosedur Analisis untuk Riset Skripsi, Tesis dan Disertasi. Penerbit PT. Elex Media Komputindo, Jakarta.

Stepanus J., BB. (2013). Pengaruh Belanja Modal dan Pendapatan Asli Daerah Terhadap Pertumbuhan Ekonomi Kabupaten/Kota di Provinsi Kalimantan Barat. Jurnal Ekonomi Daerah. 2013. (diambil pada tanggal 22 Juli 2020 dari situs neliti).

Sukirno, Sadono. 2011. Makro Ekonomi Teori Pengantar. PT. Rajagrafindo Persada ; Jakarta. 
Suparmoko, 2012. Keuangan Negara : Dalam Teori dan Praktek. Edisi Keenam, Cetakan Kedua. Yogyakarta : BPFE UGM.

Widjaja, HAW. 2002. Otonomi daerah dan Daerah Otonom. Jakarta: Raja Grafindo Persada.

Wiraswasta, Fani; Pudjiharjo M, dan Putu Mahardika Adi Saputra. (2018). Pengaruh Dana Perimbangan dan Pendapatan Asli Daerah Terhadap Pertumbuhan Ekonomi Melalui Belanja Modal di Kota dalam Wilayah Jawa Timur (Tahnu 2009-2014). Jurnal Bisnis dan Manajemen. Vol. 5. No. 2 Juni 2018. P. 170-180. (diambil pada tanggal 23 Juli 2020 dari jurnal unmer)

Yunita Anggarini dan B. Hendra Puranto. 2010. Anggaran Berbasis Kinerja. UPP STIM YKPN, Yogyakarta.

Republik Indonesia. 2004. Undang-Undang Republik Indonesia Nomor 33 Tahun 2004 tentang Perimbangan Keuangan Pemerintah Pusat Dan Daerah. Sekretariat Negara. Jakarta.

Undang-Undang Republik Indonesia Nomor 35 Tahun 2008 tentang Penetapan Peraturan Pemerintah Pengganti Undang-Undang Nomor 1 Tahun 2008 tentang Perubahan Atas UndangUndang Nomor 21 Tahun 2001 tentang Otonomi Khusus Bagi Provinsi Papua Menjadi UndangUndang. Sekretariat Negara. Jakarta.

Undang-Undang Republik Indonesia Nomor 23 Tahun 2014 tentang Pemerintah Daerah. Sekretariat Negara. Jakarta.

Undang-Undang Republik Indonesia Nomor 9 Tahun 2015 tentang Perubahan Kedua Atas UndangUndang Nomor 23 Tahun 2014 tentang Pemerintahan Daerah. Sekretariat Negara. Jakarta.

Peraturan Pemerintah Republik Indonesia Nomor 12 Tahun 2019 tentang Pengelolaan Keuangan Daerah. Sekretariat Negara. Jakarta.

Peraturan Pemerintah Republik Indonesia Nomor 55 Tahun 2005 tentang Dana Perimbangan. Sekretariat Negara. Jakarta.

Peraturan Presiden Nomor 72 Tahun 2018 tentang Rencana Kerja Pemerintah Tahun 2019. Sekretariat Negara. Jakarta. 